\title{
Оришина В.A.
}

Влияние пандемии COVID-19 на развитие дистанционных банковских услуг

Краснодарский филиал РЭУ им. Г.В. Плеханова

(Россия, Краснодар)

doi: 10.18411/lj-04-2021-20

\section{Аннотация}

В статье исследуется влияние вспышки коронавируса на банковский сектор с учетом как краткосрочных, так и долгосрочных последствий. Оценивается готовность банковской инфраструктуры к технологиям дистанционного банкинга. Приведены примеры успешного развития дистанционных банковских услуг в ведущих банках России. Сделаны выводы о перспективах развития ДБО с учетом опыта, полученного во время пандемии COVID-19.

Ключевые слова: дистанционные банковские услуги, платежные системы, пандемия COVID-19.

\section{Abstract}

The article examines the impact of the coronavirus pandemic on the banking sector, taking into account both short-term and long-term consequences. The readiness of the banking infrastructure for remote banking technologies is assessed. Examples of successful development of remote banking services in the leading banks of Russia are given. Conclusions are made about the prospects for the development of remote banking, taking into account the experience gained during the COVID-19 pandemic.

Keywords: remote banking, payment systems, COVID-19 pandemic.

Новый тип коронавируса, появившийся в конце 2019 года, во многом существенно изменил мировой порядок. 11 марта 2020 года Всемирная организация здравоохранения (BO3) объявила COVID-19 глобальной пандемией. Для борьбы со вспышкой многие страны последовали примеру Китая, где был зарегистрирован первый случай вируса, и ввели карантин, который фактически запретил большую часть деятельности людей. Эти ограничения, хотя и различались по продолжительности и жесткости, исказили как местные, так и глобальные экономические процессы. В частности, индустрия туризма испытала колоссальный спад, поскольку блокировка привела к закрытию границ. Особо можно упомянуть авиационную отрасль, которая остановилась из-за пандемии COVID-19, в результате чего крупнейшие авиакомпании мира объявили о жестких мерах по сокращению расходов, запросили государственную помощь в ожидании лучших времён. Более того, многие предприятия, особенно малые и средние предприятия (МСП), столкнулись с проблемами ликвидности из-за сокращения производственных мощностей или полного закрытия и начали увольнять часть своих сотрудников. Кроме того, непредсказуемость пандемии коронавируса привела к резкому падению мировых фондовых рынков.

Окончательное влияние пандемии коронавируса на мировую экономику еще предстоит полностью оценить. Однако уже сейчас появились многочисленные прогнозы, в том числе прогноз Международного валютного фонда (МВФ), который предсказывает более значительный экономический спад, чем во время недавнего глобального финансового кризиса (GFC) 2008-2009 годов, и худший со времен Великой депрессии. Учитывая ухудшающуюся экономическую ситуацию МВФ, удерживая \$ 1 трлн. имеющихся ресурсов, активно поддерживает свои страны-члены через различные программы кредитования.

Вышеупомянутый экономический спад оказывает крайне негативное влияние на банковский сектор. Предприятия начали страхование ликвидности и использование кредитных линий. Более того, мировые цены на акции снизились, особенно для банков 
и других финансовых посредников, а кредитные спрэды заметно выросли для бумаг с низким кредитным рейтингом в развивающихся странах. Как указано «при крайне неблагоприятном сценарии среднее соотношение капитала первого уровня к активам, взвешенным с учетом риска, вероятно, приблизится к нормативному минимуму в $8 \%$, а для некоторых банков будет значительно ниже» [3]. Несмотря на то, что нынешняя стрессовая ситуация имеет другие корни по сравнению с GFC, в настоящее время банки лучше подготовлены к последствиям кризиса с помощью регулирующих органов. Не в последнюю очередь эта готовность связана с массовым внедрением в банках информационных и цифровых технологий [1, с. 24] по сравнению с периодом двенадцатилетней давности.

Накопленный нормативный капитал, который можно было бы использовать при наихудшем сценарии в банковском секторе стран с развитой экономикой, особенно в России, уже подвергался серьезному риску, поскольку цены на акции банков значительно снизились из-за падения цен на нефть и доходность казначейских облигаций. Если предприятия столкнутся с проблемами ликвидности и начнут полностью использовать свои банковские депозиты, банки сами могут столкнуться с серьезными проблемами с ликвидностью, которые могут усугубиться, если краткосрочные кредиторы банков перестанут доверять им свои средства. Для решения этих краткосрочных и среднесрочных проблем с ликвидностью большинство центральных банков стран как с развитой, так и развивающейся экономикой отреагировали существенным снижением ставок и (или) программами предоставления ликвидности и покупки активов. Помимо этих ощутимых мер, различные регулирующие органы ослабили ряд своих требований.

Однако существует еще один важный аспект долгосрочного воздействия текущего кризиса на банковскую отрасль, а именно на банковскую экосистему. Введенные ограничения вынуждают большую часть банковских сотрудников работать удаленно, из дома. Таким образом, большинство клиентов банка вынуждены использовать каналы подключения удаленного банкинга. Это оказывает дополнительное давление на тех клиентов, которые, например, испытывают нехватку ликвидности и необходимость пересмотра условий своих кредитов. Решающую роль начинает играть хорошо развитая инфраструктура негосударственного банкинга (например, онлайн-банкинга) [7]. Эта возросшая потребность в цифровых банковских услугах может вынудить многие традиционные финансовые учреждения ускорить усилия в области цифровых инноваций. Это требует дополнительного как организационно-технического, так и правового обеспечения новых дистанционных финансовых услуг [2]. Широкий функционал системы дистанционного банковского обслуживания позволяет предоставлять клиентам уникальные услуги, разрабатывать новые сервисы и даже новые системы для их обслуживания. «Системы privateбанкинга, контроля финансов компании, различные решения, например, зарплатные или кредитные проекты, являются параллельными путями развития стандартных решений систем ДБО» [4]. В результате многие банки и кредитные союзы, не имеющие возможность самостоятельной разработки приложений для ДБО, могут обращаться к специализированным IT-фирмам за помощью в выводе на рынок более совершенных решений цифрового банкинга. Запрос на цифровые решения может стать спасательным кругом для многих IT-компаний в то время, когда венчурное финансирование не может быть вариантом из-за нехватки ликвидности. Более того, операции с наличными могут стать опасными, поскольку есть многочисленные исследования, показывающие, что «некоторые вирусы, в том числе вызывающие заболевания человека, могут сохраняться на банкнотах часами или днями, особенно при разведении в слизи» [5]. Как следствие 
этого будет продолжен курс на повсеместное внедрение систем электронных платежей с постепенным креном в сторону отечественных платежных систем, например «МИР» [6].

Рассмотрим некоторые новые дистанционные услуги и меры банков по преодолению последствий пандемии в России, появившиеся в 2020 году:

- $\quad$ С 15 апреля 2020 г. Тинькофф снижает ставки интернет-эквайринга до $1 \%$ и отменяет все минимальные комиссии по транзакциям для клиентов, которые занимаются розничными онлайн-продажами;

- 6 мая - Тинькофф Бизнес начал выдавать зарплатные кредиты под 0\% в партнерстве с МСП Банком;

- 26 марта - банк ВТБ предоставит краткосрочные кредиты предприятиям по льготным субсидированным ставкам;

- 30 марта - ВТБ запускает программы поддержки среднего и малого бизнеса;

- 31 марта - Россельхозбанк сделал бесплатным расчетно-кассовое обслуживание для микробизнеса;

- 26 апреля - Россельхозбанк начал одобрять заявки и выдавать финансирование в рамках госпрограммы кредитования на выплату заработной платы для малого бизнеса и индивидуальных предпринимателей [3].

Это только малая часть мер, на которые идут банки для адаптации к новым реалиям. Банки переходят к дистанционному режиму, трансформируя свои услуги и продолжая развиваться в условиях борьбы с пандемией коронавируса.

Подводя итог, можно сделать вывод, что даже условия пандемии имеют свои точки роста и стресс-тест приведет к появлению в банковском секторе новых дистанционных технологий, отвечающих требованиям сегодняшнего дня, которые в условиях кризиса обозначились наиболее остро. Более интенсивно будут развиваться технологии телебанкинга, онлайн-банкинга и системы бесконтактных платежей.

\section{$* * *$}

1. Верба С.Ю., Фролов Р.Н. Внедрение информационных технологий как стимулирующий фактор наращивания прибыли коммерческого банка // Вестник ИМСИТ. 2013. №3 - 4 (55 - 56). C. 24 - 25 .

2. Kolkareva I.N., Dudchenko A.V., Eremeeva A.A., Frolov R.N. Automation of financial information exchange: implementation into the Russian legislation // Lecture Notes in Networks and Systems. 2020. T. 87. - C. 155-160.

3. Коронавирус: как пандемия влияет на работу банков России. [Электронный ресурс]. - Режим доступа - URL: https://smebanking.news/ru/26870-koronavirus-kak-pandemiya-vliyaet-na-rabotubankov-rossii

4. Курицына П.О. Дистанционное банковское обслуживание в Российской Федерации: современное состояние, проблемы и перспективы развития. // Магистерская диссертация. [Электронный ресурс]. https://elar.urfu.ru/bitstream/10995/75960/1/m_th_p.o.kuritsyna_2019.pdf

5. Кухаренко Л.В., Багдасарян Е.Н. Новые формы электронного бизнеса в период пандемии COVID19: инновации и перспективы // В сборнике: Наука и образование: актуальные вопросы, проблемы теории и практики. Сборник научных трудов Национальной (всероссийской) научно-практической конференции. Краснодар, 2020. - С. 498-506.

6. Фролов Р.Н. Управление электронным бизнесом. Проектный практикум: учеб.-метод. пособие / Р.Н. Фролов, Л.В. Кухаренко. - Краснодар, 2018. - 60 с.

7. Юдин В.В. Перспективы дистанционного банковского обслуживания физических лиц // Банковские услуги. - 2018. - № 2. - С.19. 